\title{
Glider and remote sensing observations of the upper ocean response to an extended shallow coastal diversion of wastewater effluent
}

\author{
Bridget N. Seegers ${ }^{1^{*}}$, Elizabeth N. Teel ${ }^{1}$, Raphael M. Kudela ${ }^{2}$, \\ David A. Caron ${ }^{1}$, Burton H. Jones ${ }^{1,3}$
}

${ }^{1}$ Department of Biological Sciences, University of Southern California, 3616 Trousdale Parkway, AHF 301, Los Angeles, CA 90089-0371

${ }^{2}$ Ocean Sciences and Institute for Marine Sciences, University of California, Santa Cruz, 1156 High Street, Santa Cruz, CA 95064

${ }^{3}$ King Abdullah University of Science and Technology, 4700 KAUST, 23955-6900, Thuwal, Kingdom of Saudi Arabia

* Author for Correspondence: bridgetseegers@gmail.com 


\section{Abstract}

2 The Orange County Sanitation District (OCSD) diverted wastewater discharge $\left(5.3 \times 10^{8} 1 \mathrm{~d}^{-1}\right)$

3 from its primary deep $(56 \mathrm{~m})$ outfall $8 \mathrm{~km}$ offshore, to a secondary shallower $(16 \mathrm{~m})$ outfall

$4 \quad 1.6 \mathrm{~km}$ offshore for a period of three weeks. It was anticipated that the low salinity and

5 density of the effluent would cause it to rise to the surface with limited dilution, elevating

6 nutrient concentrations in near-surface waters and stimulating phytoplankton blooms in the

7 region. Three Teledyne Webb Slocum gliders and a Liquid Robotics surface wave glider were

8 deployed on transects near the outfalls to acquire high spatial and temporal coverage of

9 physical and chemical parameters before, during, and after the wastewater diversion.

10 Combined autonomous underwater vehicle (AUV) and MODIS-Aqua satellite ocean color

11 data indicated that phytoplankton biomass increased in the upper water column in response to

12 the diversion, but that the magnitude of the response was spatially patchy and significantly

13 less than expected. Little evidence of the plume or its effects was detectable $72 \mathrm{~h}$ following

14 the diversion. The effluent plume exhibited high rates of dilution and mixed throughout the

15 upper $20 \mathrm{~m}$ and occasionally throughout the upper $40 \mathrm{~m}$ during the diversion. Rapid plume

16 advection and dilution appeared to contribute to the muted impact of the nutrient-rich effluent

17 on the phytoplankton community in this coastal ecosystem.

18 Key Words: phytoplankton; waste-water treatment; sewage; outfalls; AUVs; Southern

19 California Bight 


\section{Introduction}

The coastline of the Southern California Bight extends $\sim 700 \mathrm{~km}$ along the west coast of North America from Point Conception, California, to just south of San Diego, California. Some parts of the Bight are highly impacted by human activities, with nearly 20 million people situated centrally along the coast in the greater Los Angeles region. This region contributes significantly to nutrient availability in near-shore waters, in part due to large ocean discharges of treated sewage effluent from several subsurface and offshore outfalls. A recent study indicated that inorganic nitrogen $(\mathrm{N})$ in effluent discharged into the central Southern California Bight was a substantial contributor to the region's N budget (Howard et al. 2014).

These large outfalls have been designed to minimize the impact of effluent on local nutrient budgets by discharging into relatively deep water $(>50 \mathrm{~m})$ at significant distances from shore $(\approx 5-8 \mathrm{~km})$, and sufficiently mixing the wastewater such that diluted discharge plume remains below the pycnocline. However, maintenance or repairs occasionally require that effluent must be redirected to older outfalls that are shallower and closer to shore. Positive buoyancy of the effluent plume, due to low salinity and density, enhances the potential for transport of nutrient-rich effluent into surface waters, especially during effluent diversion events. Such diversions have the potential to stimulate the standing stock of phytoplankton in the area of effluent discharge due to increased nutrient inputs. Hyperion Treatment Plant of the City of Los Angeles carried out such a diversion in November 2006 through its near-shore outfall located $1.6 \mathrm{~km}$ from shore in Santa Monica Bay. Although the Hyperion diversion lasted only 50 hours, a significant, albeit patchy phytoplankton bloom ensued. The bloom was dominated by Cochlodinium sp., a toxic dinoflagellate, reaching 
chlorophyll- $a$ concentrations of $100 \mathrm{mg} \mathrm{m}^{-3}$ within 4-7 days of the diversion (Reifel et al., 2013). The Hyperion treatment plant diversion took place only $65 \mathrm{~km}$ north of the study site in San Pedro Bay described here.

The Orange County Sanitation District (OCSD) conducted repairs of its primary offshore outfall in September 2012. Effluent was diverted to a secondary, shallow outfall located at 16 $\mathrm{m}$ depth and only $1.6 \mathrm{~km}$ from shore for a period of 3 weeks. It was expected that the OCSD diversion might elicit a major phytoplankton bloom in the near-shore coastal ecosystem, based on observations following the 2006 Hyperion diversion. The timing of the OCSD diversion during late summer is a period when local waters are highly stratified due to warm surface waters and are generally nutrient depleted. Predictions of the impact of effluent discharge on the phytoplankton community during the 3-week OCSD diversion were presented in an Environmental Impact Report. The report indicated that advective mixing and tidal modulation of the plume could yield parcels of coastal water containing up to $42 \mu \mathrm{M}$ ammonium, resulting in an algal bloom with 40-50 $\mathrm{mg} \mathrm{m}^{-3}$ chlorophyll- $a$ (OCSD, 2011; Jones and Caron, 2011). These values are equivalent to the largest phytoplankton blooms observed in this region (Kim et al., 2009; Seubert et al., 2013). Concern over the potential for harmful algal blooms and coastal water quality led to an intense monitoring and research effort during the OCSD diversion.

A combination of glider and satellite remote sensing was used to determine spatial and temporal responses of the phytoplankton community to the OCSD wastewater diversion. Observations began two weeks before the diversion to establish pre-diversion conditions and continued during and after the diversion to capture responses to the expected shallow effluent 
plume. The glider sensors allowed tracking of both the effluent plume and surface and subsurface phytoplankton responses.

\section{Methods}

\subsection{Location and effluent composition}

OCSD discharges treated wastewater into the San Pedro Bay, California, off the coast of Orange County in the central Southern California Bight (Fig. 1). The facility typically discharges approximately $5.3 \times 10^{8} 1 \mathrm{~d}^{-1}$ through a primary outfall diffuser located $8 \mathrm{~km}$ offshore at a depth of $56 \mathrm{~m}$. OCSD conducted a three-week repair to the primary outfall from 11 September to 3 October 2012, and diverted effluent to a shallower (16 m) outfall located $1.6 \mathrm{~km}$ from shore. The secondary effluent pipe included a $295 \mathrm{~m}$ long diffuser section, outfitted with 120 circular effluent ports of $15.9 \mathrm{~cm}$ diameter designed to increase initial dilution rates (OCSD, 2009). The effluent is especially N-enriched relative to phosphorus (P) with N:P $\sim 100: 1$, ammonium $\left(\mathrm{NH}_{4}{ }^{+}\right) \approx 2.1 \mathrm{mM}$ and phosphate $\left(\mathrm{PO}_{4}{ }^{3-}\right) \approx 8.5 \mu \mathrm{M}$ (Lyon and Sutula, 2011). Although not reported for OCSD effluent, silicate $\left(\mathrm{SiO}_{4}\right)$ is often present in sewage effluent at concentrations $>550 \mu \mathrm{M}$ (Petrenko et al., 1997). Responses of the phytoplankton community to such large nutrient additions were monitored using a variety of in-situ and remote sensing instrumentation.

\subsection{Slocum gliders}

Teledyne Webb Slocum gliders (North Falmouth, Massachusetts) and a Liquid Robotics (Sunnyvale, California) surface Wave Glider were deployed during the diversion along transect lines near the outfall pipes to obtain spatial and temporal coverage of biological and physical properties before, during, and after the diversion. Gliders are superior to shipboard 
measurements for tracking effluent plumes, given the high spatial and temporal variability of water-quality responses (Rogowski et al., 2013).

Slocum gliders were equipped with a flow-through Seabird CTD, WET Labs ECO Puck fluorometers (excitation $470 \mathrm{~nm} / \mathrm{emission} 695 \mathrm{~nm}$ ) for sensing chlorophyll- $a$, colored dissolved organic matter (CDOM) (excitation 370/emission $460 \mathrm{~nm}$ ), and phycoerythrin (excitation 540/emission $570 \mathrm{~nm}$ ), and WET Labs ECO Puck Backscattering Sensors at 532, 660, and $880 \mathrm{~nm}$. Estimated vertical resolution was $30 \mathrm{~cm}$ for glider fluorescence and backscattering ECO Pucks, and $60 \mathrm{~cm}$ for the CTD. Horizontal surface resolution of a Slocum glider is approximately three times the dive depth with an estimated horizontal speed of $0.3 \mathrm{~m}$ $\mathrm{s}^{-1}$. Data were binned to $1 \mathrm{~m}$ for profile analysis. Slocum gliders were removed every 22-26 d for a battery change, cleaning, and CDOM and chlorophyll- $a$ calibrations following protocols described in Cetinić et al. (2009). The gliders were not used to estimate effluent dilution rates because calibration curves for this purpose were not developed for the gliders.

We deployed Slocum gliders two weeks prior to the diversion until two weeks after (29 August - 16 October), covering three along-coast zigzag transects, designed to maximize spatial coverage on and off the shelf, and temporal resolution around the outfall. The glider paths were based on the assumption that the primary direction of transport of the plume would be along-coast away from the outfall, and that the cross-section of the plumes (major gradients) would be oriented cross-shelf (Hamilton et al., 2006). The zigzag pattern minimized the number of waypoints necessary to move the glider along and across the shelf, which can increase glider efficiency. Slocum gliders profiled from 3 to $90 \mathrm{~m}$ depth, or $5 \mathrm{~m}$ above the bottom when on the shelf. Two glider transects covered the near-shore from $\sim 20 \mathrm{~m}$ isobath to beyond the shelf break. The northern transect covered an along-shore distance 12 
$\mathrm{km}$ north/northwest of the outfalls, while the southern transect covered a distance $17 \mathrm{~km}$ down-coast from the outfalls. Along-shore coverage was greater to the south, based on the expectation that near-surface currents tend to be southward during late summer (Dong et al., 2009, Hamilton et al., 2006, Noble et al., 2009). Northern and southern transects overlapped near the outfalls to maximize coverage in their vicinities (Fig. 1). An offshore glider transect covered the region out to $20 \mathrm{~km}$ offshore from the near-shore outfall to detect offshore transport and subsequent phytoplankton blooms (Fig. 1).

\subsection{Effluent characterization used for tracking the plume}

The ability of gliders to track both the effluent plume and its influence on the coastal ecosystem required reliable identification of the plume. A variety of approaches have been used previously to map these plumes. Early efforts relied on $\mathrm{NH}_{4}{ }^{+}$and coliform bacteria as unambiguous tracers of the plume as concentrations and abundances of these constituents in effluent exceed ambient values (e.g. Jones et al., 1987). Later work identified the plumes on the basis of temperature, salinity, turbidity, and chlorophyll- $a$ fluorescence anomalies (Washburn et al., 1992, Wu et al., 1994). Previous studies in San Pedro Bay used a combination of salinity and fecal indicators to track the plume (Jones et al., 2002). Todd et al. (2009) combined glider measurements of temperature, salinity, and density to detect effluent in water column profiles.

Advances of optical instruments and autonomous underwater vehicles (AUV) have expanded the tools available to track effluent plumes. Recent work showed CDOM is a robust and reliable tracer (Petrenko et al., 1997, Rogowski et al., 2012; 2013). Rogowski et al. (2012) used salinity, temperature, and CDOM measurements from a REMUS (Remote

Environmental Monitoring UnitS) to successfully track an effluent plume off the southern 
California coast near San Diego. Their results demonstrated that tracking the plume using CDOM as a tracer was superior to salinity gradients.

We used low salinity and elevated CDOM to identify the effluent plume with glider data. The inherent variability of vertical profiles made it difficult to identify the plume based on a specific salinity or CDOM value. Instead, we used salinity and CDOM anomalies for individual profiles as evidence of the effluent plume. Our approach was similar to Todd et al. (2009) who used salinity anomalies to identify the effluent plume. Representative profiles of mean salinity and CDOM were created using profiles unaffected by effluent. All glider profiles $>12 \mathrm{~km}$ from the offshore ocean outfall were used to establish the mean profile free from the effects of effluent. Mean profiles were then used to sort individual profiles. Profiles with salinity anomalies < - 0.04 (i.e., value used by Todd et al. 2009), and a corresponding $\mathrm{CDOM}$ anomaly $>1.25 \mathrm{ppb}$ quinine sulfate equivalents (QSE), were considered plume profiles. This characterization of plume and non-plume profiles was used to track the effluent plume throughout the diversion. Unpaired, two-sample $t$-tests using Matlab were used to determine significant differences of plume and non-plume values at each depth. In addition, large sample sizes supported the use of effect size using Cohen's d, a value that expresses the mean difference between two groups in standard deviation units. Cohen (1988) suggested that $d$ from 0.2-0.5 correspond to a small effect size, $d$ from $0.5-0.8$ to a moderate effect size, and $d>0.8$ a large effect size.

\subsection{Wave Glider}

Wave Glider SV2 (Liquid Robotics, Sunnyvale, California) is an autonomous surface vehicle that uses ocean-wave energy for propulsion. We equipped the Wave Glider with an above-surface Airmar PB200WX weather station, a SeaBird GPCTD, and a Turner Designs 
model C3 fluorometer to measure CDOM, chlorophyll- $a$, and crude oil at a depth of 20-30 $\mathrm{cm}$. CDOM and chlorophyll- $a$ fluorescence were reported in relative fluorescence units (RFUs) to identify patterns and trends. The Wave Glider was deployed 4 days prior to the diversion on 7 September and was removed on 19 September. It completed six traverses of the near-shore southern glider transect, providing overlapping coverage with the Slocum glider (Fig. 1). CTD data collection ended on 15 September as the CTD was sheared off the Wave Glider.

\subsection{MODIS}

Ocean color images from the Moderate Resolution Imaging Spectroradiometer (MODIS) on NASA's Aqua satellite at $250 \mathrm{~m}$ resolution provided expanded regional coverage of nearsurface chlorophyll- $a$ and CDOM during the diversion. Previous studies have successfully used MODIS data in the near-shore and shelf region of the Southern California Bight to track surface plumes and phytoplankton responses (e.g., Nezlin et al., 2008, Lahet and Stramski, 2010). We acquired MODIS Aqua data for this study as Level 0 files from the NASA Ocean Biology Processing Group, and processed them to Level 2 using SeaDAS 7.0 software with the NIR/SWIR atmospheric correction. Chlorophyll- $a$ concentrations were calculated using the OC2 algorithm, and CDOM absorption $\left(\mathrm{a}_{\mathrm{g}}\right)$ was determined using the Quasi Analytical Algorithm (QAA) (Lee et al., 2002, 2007). Ocean color images from MODIS-Aqua are described in more detail by Gierach et al. (this issue).

\section{Results}

\subsection{Pre-diversion conditions}

Slocum gliders were deployed nearly two weeks before the near-shore diversion (29 August to 11 September), providing baseline data for pre-diversion conditions. Pre-diversion 
conditions showed strong summer stratification with sea-surface temperatures from $18-22^{\circ} \mathrm{C}$ (Fig. 2A). Monthly sea-surface temperatures (2003-2013) from MODIS Aqua revealed that September temperatures were above average with an anomaly of $1.37^{\circ} \mathrm{C}$ (Kudela et al., this issue). The distribution of phytoplankton was characterized by a subsurface chlorophyll- $a$ maximum centered at $38.6 \pm 6.8 \mathrm{~m}$. Maximum chlorophyll- $a$ averaged from all profiles offshore of the shelf break was $6.0 \pm 2.2 \mathrm{mg} \mathrm{m}^{-3}$ ( $n=870$; Fig. 2B). The subsurface chlorophyll maximum was shallower over the shelf $(27.6 \pm 5.9 \mathrm{~m})$, with maximum chlorophyll- $a$ averaging $5.3 \pm 1.8 \mathrm{mg} \mathrm{m}^{-3}(n=923)$.

The effluent plume identified by high CDOM and reduced salinity was evident in the section nearest the primary outfall during the pre-diversion period (Figure 2D-E), but was also observed in both directions along the coast from the outfall. The effluent plume disrupted the subsurface chlorophyll layer as effluent with low chlorophyll- $a$ shoaled in the water column. Both the center section and the section to the northwest (left) showed reduced chlorophyll- $a$ fluorescence (Fig. 2B), coinciding with the plume identified by elevated CDOM (Fig. 2D).

We used the combination of elevated CDOM and reduced salinity anomalies in glider data to detect plume profiles, enabling us to map the effluent plume during the pre-diversion period (Fig. 3, top panel). Of 1793 pre-diversion profiles, 534 (30\%) were considered plume profiles and 1259 (70\%) non-plume profiles. Most of the plume profiles were located on the shelf to the west/northwest of the outfall (Fig. 3).

The Wave Glider was deployed on 7 September for four days to obtain pre-diversion surface observations at 20-30 cm depth. Pre-diversion sea-surface temperatures ranged from 
20-22 ${ }^{\circ} \mathrm{C}$ along the Wave Glider transect (Fig. 4). On-shelf sea-surface temperatures and salinities were lower than off-shelf measurements.

Pre-diversion ocean color imagery from MODIS Aqua for 2 September provided a regional overview of near-surface conditions (Fig. 5, top). The nearshore area within $3 \mathrm{~km}$ of shore had elevated chlorophyll- $a$ and CDOM signals. However, there were no chlorophyll- $a$ or CDOM patterns associated with the outfall pipes during the pre-diversion period.

Chlorophyll- $a$ was generally $<1 \mathrm{mg} \mathrm{m}^{-3}$ near the outfall pipes, and CDOM absorption was also low with values less than $0.1 \mathrm{~m}^{-1}$, corresponding to low CDOM concentrations.

\subsection{Diversion conditions}

Mean profiles for each variable were compiled from glider surveys for the $22 \mathrm{~d}$ diversion to characterize conditions. The diversion profiles were separated into plume and non-plume profiles to examine the influence of effluent on the coastal ecosystem. The majority of plume profiles during the diversion were located on the shelf west/northwest of the outfall, a distribution similar to the pre-diversion period (Fig. 3, top and middle panels). Warm water persisted at the surface for most of the region throughout the diversion, as during the prediversion period (Fig. 6A). However, plume profiles had slightly cooler temperatures in the upper $30 \mathrm{~m}$ than non-plume profiles (6A). A subsurface chlorophyll- $a$ maximum was a common feature of non-plume profiles throughout the diversion (Fig. 6B). In comparison, plume profiles had increased surface chlorophyll- $a$, with significantly higher concentrations in the upper $33 \mathrm{~m}$ than non-plume profiles $(t$-test, $p<0.05)$. We observed a 2-3 fold increase of mean chlorophyll- $a$ at depths shallower than $14 \mathrm{~m}$ compared to the mean non-plume profile (Fig. 6B). During the diversion, 733 of the 2943 (25\%) glider profiles had maximum chlorophyll- $a$ in the top $20 \mathrm{~m}$, with a maximum surface chlorophyll- $a$ averaging $5.09 \pm 2.75$ 
$\mathrm{mg} \mathrm{m}^{-3}$. Cohen's effect-size values $(d>0.8)$ for chlorophyll- $a$ throughout the upper $12 \mathrm{~m}$ confirmed a significant effect of the plume (Fig. 6E). The effect-size values $(0.5<d<0.8)$ corresponded to a moderate impact from $13 \mathrm{~m}$ to $33 \mathrm{~m}$, with little effect size deeper than $33 \mathrm{~m}$ $(d<0.5)$. In addition to elevated surface chlorophyll- $a$, plume profiles $(n=1305)$ had significantly lower salinity and higher CDOM than non-plume profiles in the upper $42 \mathrm{~m}(n=$ 1649), with the largest differences in the upper $20 \mathrm{~m}$ (Fig 6C,D,E).

Phytoplankton responses during the diversion were of modest magnitude and patchy spatially, with increased chlorophyll- $a$ in close proximity to the effluent plume (Fig. 7B). A notable chlorophyll- $a$ feature in the upper water column extended down-coast from the outfall from 29 September to 3 October (diversion days 17-22). Chlorophyll- $a$ in this patch exceeded $8 \mathrm{mg} \mathrm{m}^{-3}$, while chlorophyll- $a$ fluorescence indicated concentrations $<2 \mathrm{mg} \mathrm{m}^{-3}$ in nearsurface waters for most of the surrounding region, and $<5 \mathrm{mg} \mathrm{m}^{-3}$ in the subsurface chlorophyll- $a$ maximum (Fig. 7B). Increased chlorophyll- $a$ directly coincided with increased CDOM (Fig. 7D) and reduced salinity (Fig. 7E) in the effluent plume. The effluent plume of reduced salinity had slightly lower temperatures than surrounding surface waters, reducing the density difference between the effluent plume and the ambient ocean, and perhaps enhancing mixing (Fig. 7A).

We surveyed surface waters using a Wave Glider throughout the diversion area until 19 September. Apparent in Wave Glider data were the patchy distribution of near-surface water affected by the plume and the patchiness of the phytoplankton response (Fig. 4). The distribution of surface effluent, indicated by elevated CDOM and reduced salinity, was patchy throughout the area surveyed (Fig. 4). Chlorophyll- $a$ fluorescence as RFU showed a limited increase of chlorophyll- $a$ from 11-13 and 15-17 September. 
Ocean color imagery from MODIS Aqua revealed effects of the diversion on surface chlorophyll- $a$ and CDOM (Fig. 5; 20 September and 1 October). Responses were very localized with limited offshore and along-shore signals. Chlorophyll- $a$ and CDOM had similar distributions in the region near the outfall pipe. Imagery from 20 September and 1 October showed highest chlorophyll- $a$ on the shelf to the west/southwest and a narrow band of elevated chlorophyll- $a$ along the coast to the southeast. CDOM values indicative of diluted effluent plume at the surface overlapped with the elevated chlorophyll- $a$. There was good agreement between locations of elevated CDOM derived from MODIS-Aqua imagery and many of the glider plume profiles (Fig. 3; middle panel).

\subsection{Post-diversion}

Water-quality properties measured within $72 \mathrm{~h}$ of the end of the diversion retained little evidence of its occurrence. Glider profiles conducted on 5-8 October, 3-6 days after the diversion, showed low surface chlorophyll- $a$ accompanied by low CDOM in much of the region (Fig. 8). Ocean color imagery from MODIS-Aqua for 8 October showed no increase of chlorophyll- $a$ or CDOM near the outfall pipes (Fig. 5, bottom panel), suggesting the diversion had minimal lasting influence on regional conditions.

\section{Discussion}

\subsection{Impact of effluent diversion on phytoplankton biomass}

Multiple data sources using in-situ sensors and satellite imagery enabled us to characterize the impact of a three-week effluent diversion by OCSD with high spatial and temporal resolution. The diversion produced a small, local phytoplankton response at the near-shore effluent discharge. This response was less pronounced than predicted by the pre-diversion Environmental Impact Report (OCSD, 2011). Those predictions were based on an earlier 
diversion in the region (Hyperion Treatment Plant of the City of Los Angeles), however, where a massive phytoplankton response occurred with chlorophyll- $a>100 \mathrm{mg} \mathrm{m}^{-3}$ (Reifel et al., 2013).

Autonomous observations in this study indicated the modest phytoplankton response and short-term impacts of the diversion could be explained, in part, by high mixing rates of the plume into surrounding coastal waters. High dilution rates would limit nutrient concentrations from the effluent and reduce the potential for a large phytoplankton response. Elevated CDOM fluorescence from glider profiles showed the plume was often mixed throughout the surface $40 \mathrm{~m}$ (Fig. 6C) compared to the dense surface plume that was observed during the earlier Hyperion diversion (Reifel et al., 2013). Warm ambient ocean water minimized density differences between effluent and the surrounding ocean, possibly allowing increased mixing of low salinity effluent throughout the surface layer.

Differences of coastline topography and the design of the near-shore outfalls for Hyperion and OCSD may also contribute to higher mixing rates of effluent plumes at the OCSD secondary outfall. A modeling study of effluent dispersion found Santa Monica Bay documented much higher retention rates when compared to the San Pedro Basin, contributing to higher phytoplankton biomass observed during the Hyperion diversion (Uchiyama et al., 2014). Moreover, the secondary diversion outfall of OCSD includes a long diffuser section that probably increased initial dilution rates (OCSD, 2009) compared to the Hyperion plant that lacks a diffuser discharge. Lagrangian drifters tracked the plume during the diversion using salinity measurements to estimate effluent dilution. These dilutions were generally > 100:1 within 500 to $2000 \mathrm{~m}$ of the secondary outfall pipe (Ohlmann, personal communication). In addition, Caron et al (this issue) used salinity measurements on a set of moorings near the 
discharge to estimate effluent dilution from 100:1 to 1000:1. Comparable dilution estimates for the Hyperion diversion were much lower at 11:1 (Reifel et al., 2013).

Although elevated phytoplankton biomass generally followed effluent plume dispersal throughout the diversion, maximum chlorophyll- $a$ measurements were not associated with highest plume concentrations for several reasons: (1) the effluent itself lacked chlorophyll- $a$ and we observed the effluent plume diluted or displaced the subsurface chlorophyll- $a$ maximum; (2) development of elevated phytoplankton biomass would be expected only after phytoplankton had sufficient time (days) to respond to the nutrient inputs; (3) chemical and biological controls associated with the effluent plume may have limited phytoplankton responses at the highest plume concentrations. Kudela et al. (this issue) reported inhibition of photosynthesis by disinfection byproducts released in the plume, and Caron et al. (this issue) reported substantial increases of bacterial biomass during the diversion, resulting in significant uptake of nutrients by that assemblage. These factors, together with rapid mixing and movement of the plume documented in this study, precluded the anticipated massive increase of phytoplankton biomass during the OCSD diversion based on the observed response previously from the more northerly Hyperion Treatment Plant diversion.

\subsection{Subsurface effluent plume impacts on phytoplankton community}

Effluent from the offshore $(8 \mathrm{~km})$ outfall of OCSD represents a continuous nutrient input to the San Pedro Shelf spanning > 40 years. During pre-diversion conditions the gliderobserved plume reached density equilibrium at $47 \mathrm{~m}$ (25.4 $\mathrm{kg} \mathrm{m}^{-3}$ isopycnal), similar to earlier glider observations in the region (Todd et al., 2009), and to a modeling study that showed the plume stabilized at a depth of $46 \mathrm{~m} \pm 5 \mathrm{~m}$ (Uchiyama et al., 2014). Our observations indicate subsurface inputs of anthropogenic nutrients interact directly with the subsurface 
phytoplankton community (Fig. 2B). Although the extent of plume profiles in our observations is limited, effluent could have a variety of effects in addition to supplying nutrients. The community composition of phytoplankton, including harmful algal bloom (HAB) species, is sensitive to anthropogenic nutrient inputs (e.g. Anderson et al., 2006, Kudela et al., 2008, Loureiro et al., 2009, Glibert et al., 2015). Previous work in the San Pedro Basin demonstrated blooms of toxic Pseudo-nitzschia sp. appear in offshore, subsurface waters and can act as seed populations for surface blooms (Seegers et al., 2015). Impacts of effluent on dynamics of the subsurface phytoplankton community thus have ramifications for the San Pedro Basin and deserve further study.

\section{Conclusions}

The three-week effluent diversion by OCSD to a shallow, near-shore outfall supported a modest stimulation of chlorophyll- $a$ in the top $30 \mathrm{~m}$ of the water column, although the increase was patchy and short-lived. This phytoplankton response was weaker than anticipated based on a mass balance model and a previous outfall diversion in coastal waters of southern California. The models predicted limited mixing, but observations showed that the effluent plume was often mixed throughout the upper $20 \mathrm{~m}$ and at times down to $40 \mathrm{~m}$. Mixing and increased dilution explained, in part, the modest increase of phytoplankton biomass. We suggest the important role of dilution in mediating phytoplankton responses to effluent diversions should be considered by managers to mitigate ecological impacts of outfall repairs and diversions. Our observations demonstrate that subsurface phytoplankton interact with effluent plumes during summer stratified periods characterized by a relatively deep subsurface chlorophyll- $a$ maximum. More research is needed to determine long-term impacts 
of effluent on community composition of phytoplankton, specifically in promoting the occurrence of potentially deleterious HABs.

\section{Acknowledgements}

Matthew Ragan, Xiao Liu, Carl Oberg, Dario Diehl, Kendra Hayashi Negrey, Christopher Wahl, and Evan Randall-Goodwin were integral members of the glider team during the diversion. Arvind Pereira assisted with computer programming, glider operations, and data processing. Nick Rollins and Mattias Cape assisted with Matlab coding. Captain Ray Arntz and Captain Kyaa Heller of the SunDiver assisted with glider deployments. We also thank the staff members of the Wrigley Marine Science Center, especially Lauren Czarnecki, Kellie Spafford, Captain Trevor Oudin, and Captain Gordon Boivin, for their consistent support throughout the diversion glider effort. This research was supported by National Oceanic and Atmospheric Administration grants NA11NOS4780052, NA11NOS4780030, and

NA08OAR4320894, National Science Foundation through RAPID award OCE1251573, Orange County Sanitation District research funds, the University of Southern California Provost Fellowship and Gold Family Graduate Fellowship, and King Abdullah University of Science and Technology. This is NOAA ECOHAB publication number 823. 


\section{References}

Anderson, C.R., Brzezinski, M.A., Washburn, L. Kudela, R.M., 2006. Circulation and environmental conditions during a toxigenic Pseudo-nitzschia australis bloom in the Santa Barbara Channel, California. Mar. Ecol. Prog. Ser. 327, 119-133.

Caron, D.A., Gellene, A.G., Smith, J., Seubert, E.I, Campbell, V., Sukhatme, G.S., Seegers, B, Jones, B.H., Lie, A.A.Y., Terrado, R, Howard, M.D.A., Kudela, R.M., Hayashi,K., Ryan, J., Birch, J, Demir-Hilton, E., Yamahara, K., Scholin, C., Mengel, M., Robertson, G., 2016. Response of the phytoplankton and bacterial communities during a wastewater effluent diversion into nearshore coastal waters. Estuar. Coast. Shelf Sci. (this issue).

Cohen, J.,1988. Statistical power analysis for the behavioral sciences. (2 ${ }^{\text {nd }}$ Edition) New Jersey, Lawrence Earlbaum Associates.

Dong, C., Idica, E., McWilliams, J., 2009. Circulation and multiple-scale variabiltiy in the Southern California Bight. Progr. Oceanogr. 82, 168-190.

Gierach, M.M, Holt, B., Trinh, R., Pan, B., Rains, C., 2016. Satellite detection of wastewater diversion plumes in southern California. Estuar. Coast. Shelf Sci. (this issue).

Glibert, P.M., Wilkerson, F.P., Dugdale, R.C., Raven, J.A., Dupont, C.L., Leavitt, P.R., Parker, A.E., Burkholder, J.M., Kana, T. M., 2015. Pluses and minuses of ammonium and nitrate uptake and assimilation by phytoplankton and implications for productivity and community composition, with emphasis on nitrogen-enriched conditions. Limnol. Oceanogr. doi: 10.1002/lno.10203

Hamilton, P., Noble, M.A., Largier, J., Rosenfeld, L.K., Robertson, G., 2006. Cross-shelf subtidal variability in San Pedro Bay during summer, 2001. Cont. Shelf Res. 26, 681-702. 
Howard, M.D.A., Sutula, M., Caron, D.A., Chao, Y., Farrara, J.D., Frenzel, H., Jones, B.H., Robertson, G., McLaughlin, K., Sengupta, A., 2014. Anthropogenic nutrient sources rival natural sources on small scales in the coastal waters of the Southern California Bight. Limnol. Oceanogr. 59, 285-297.

Howard, M.D.A., Ladizinsky, N., Cochlan, W.P., Kudela, R.M., 2007. Nitrogenous preference of toxigenic Pseudo-nitzschia australis (Bacillariophyceae) from field and laboratory experiments. Harmful Algae 6, 206-217.

Jones, B.H., Bratkovich, A., Dickey, T.D., Kleppel, G., Steele, A., et al. 1987. Variability of physical, chemical, and biological parameters in the vicinity of an ocean outfall plume. Presented at Third International Conference on Stratified Flows, Pasadena, CA.

Jones, B.H., Caron, D.A., 2011. Anticipated biological response to extended discharge from a nearshore, shallow outfall. Fountain Valley, CA, Orange County Sanitation District, pp. 116.

Jones, B.H., Noble, M., Dickey, T., 2002. Hydrographic and particle distributions over the Palos Verde Continental Shelf: Spatial, seasonal and daily variability, Cont. Shelf Res. 22, 945-965.

Kim, H.-J., Miller, A.J., McGowan, J., Carter, M.L., 2009. Coastal phytoplankton blooms in the Southern California Bight. Prog. Oceanogr. 82, 137-147.

Kudela, R.M., Lane, J.Q., Cochlan, W.P., 2008. The potential role of anthropogenically derived nitrogen in the growth of harmful algae in California, USA. Harmful Algae 8, $103-110$. 
Kudela, R.M., Lucas, A.J., Hayashi, K., Howard, M., McLaughlin, K., 2016. Death from below: Investigation of inhibitory factors in bloom development during a wastewater effluent diversion. Estuar. Coast. Shelf Sci. (this issue)

Lahet, F., Stramski, D., 2010. MODIS imagery of turbid plumes in San Diego coastal waters during rainstorm events. Remote Sens. Environ. 114, 332-344.

Lee, Z.P., Carder, K.L., Arnone, R., 2002. Deriving inherent optical properties from water color: a multiband quasi-analytical algorithm for optically deep waters. Appl. Optics 41, 2705-2714.

Lee, Z.P., Weidemann, A., Kindle, J., Arnone, R., Carder, K.L., Davis, C., 2007. Euphotic zone depth: its derivation and implications for ocean-color remote sensing. J. Geophys. Res. 112, C03009.

Lyon, G.S., Sutula, M.A., 2011. Effluent discharges to the Southern California Bight from large municipal wastewater treatment facilities from 2005 to 2009. In: Schiff, K., Miller, K. (Eds.), Southern California Coastal Water Research Project Annual Report 2011, Costa Mesa, CA.

Nezlin, N.P., DiGiacomo, P.M., Diehl, D.W., Jones, B.H., Johnson, S.C., Mengel, M.J., Reifel, K.M., Warrick, J.A., Wang, M., 2008. Stormwater plume detection by MODIS imagery in the southern California coastal ocean. Estuar. Coast. Shelf Sci. 80, 141-152.

Noble, M., Jones, B.H., Hamilton, P., Xu, J., Robertson, G., Rosenfeld, L. Largier, J., 2009. Cross-shelf transport by shoaling internal tides in San Pedro Bay, CA. Cont. Shelf Res. $29,1768-1785$. 
OCSD (Orange County Sanitation District), 2009. One Mile Ocean Outfall Cleaning Report. Prepared by Undersea Graphics, Inc., Torrance, CA.

OCSD (Orange County Sanitation District), 2011. Outfall Land Section and OOBS Piping Rehabilitation Draft Environmental Impact Report, Vol. 2. Appendices. http://www.ocsd.com/Home/ShowDocument?id=10785.

Petrenko, A.A., Jones, B.H., Dickey, T.D., LeHaitre, M., Moore, C., 1997. Effects of a sewage plume on the biology, optical characteristics, and particle size distributions of coastal waters. J. Geophys. Res. - Oceans 102, 25061-25071.

Reifel, K.M., Corcoran, A.A., Cash, C., Shipe, R., Jones, B.H., 2013. Effects of a surfacing effluent plume on a coastal phytoplankton community. Cont. Shelf Res. 60, 38-50.

Rogowski, P., Terrill, E., Otero, M., Hazard, L., Middleton, W., 2013. Ocean outfall plume characterization using an autonomous underwater vehicle. Wat. Sci. Technol. 67, 925933.

Rogowski, P., Terrill, E., Otero, M., Hazard, L., Middleton, W., 2012. Mapping ocean outfall plumes and their mixing using autonomous underwater vehicles. J. Geophys. Res. Oceans 117, C7.

Seegers, B.N., Birch, J.M., Marin, III R., Scholin, C.A., Caron, D.A., Seubert, E.L., Howard, M.D.A., Roberston, G.L., Jones, B.H., 2015. Subsurface seeding of surface harmful algal blooms observed through the integration of autonomous gliders, moored Environmental Sample Processors, and satellite remote sensing in Southern California. Limnol.Oceanogr. 60, 754-764. 
Seubert, E.L., Gellene, A.G., Howard, M.D.A., Connell, P., Ragan, M., Jones, B.H., Runyan, J., Caron, D.A., 2013. Seasonal and annual dynamics of harmful algae and algal toxins revealed through weekly monitoring at two coastal ocean sites off southern California, USA. Environ. Sci. Pollution Res. 20, 6878-6895.

Todd, R.E., Rudnick, D.L., Davis, R.E., 2009. Monitoring the greater San Pedro Bay region using autonomous underwater gliders during fall of 2006. J. Geophys. Res. 114, C06001.

Uchiyama, Y., Idica, E.Y., McWilliams, J.C., Stolzenbach, K.D., 2014. Wastewater effluent dispersal in Southern California Bays. Cont. Shelf Res. 76, 36-52.

Washburn, L., Jones, B.H., Bratkovich, A., Dickey, T.D., Chen, M.S., 1992. Mixing, dispersion, and resuspension in vicinity of ccean waste-water plume. J. Hydraul. EngAsce 118, 38-58.

Wu, Y.C., Washburn, L., Jones, B.H., 1994. Buoyant plume dispersal in a coastal environment - evolving plume structure and dynamics. Cont. Shelf Res. 14, 1001-1023. 
Figure 1. Southern Californai Bight with inset indicating the study area for the Orange County Sanitation District diversion. Transect lines are indicated for the Slocum glider and Wave Glider in San Pedro Bay near Newport Beach. Primary outfall pipe (bold dark grey), diversion outfall (bold black), and 20 and $60 \mathrm{~m}$ isobaths are also shown.

Figure 2. Example of pre-diversion Slocum glider curtain plots (29 August to 3

September) showing temperature (A), chlorophyll-a fluorescence (B), Sigma $\theta$ (C), CDOM fluorescence (D), salinity (E), and the path of the transect in dark grey with the transects covered throughout the entire pre-diversion sampling in light grey $(\mathrm{F})$. Coastline depicted on the top, right of each image, and bathymetry in brown beneath the glider curtain plots. Offshore outfall (red) and the near-shore diversion outfall (bold black) are shown offshore from Newport Beach.

Figure 3. Locations of plume profiles and non-plume profiles from pre-diversion (top), during the diversion (middle), and post-diversion (bottom). Also, shown is the OCSD offshore outfall (bold dark grey), the nearshore diversion outfall (bold black), and the $20 \mathrm{~m}$ and $60 \mathrm{~m}$ isobaths.

Figure 4. Maps of chlorophyll- $a$, CDOM, temperature, and salinity at $20 \mathrm{~cm}$ depth from Wave Glider for pre-diversion (top panels) and diversion periods (middle and bottom panels). Offshore outfall (red) and near-shore diversion outfall (bold black) are shown. Wave Glider CTD was sheared off 15 Sept and no temperature or salinity data are available after that date.

Figure 5. Pre-diversion, diversion, and post-diversion estimates of chlorophyll- $a$ (left panels) and CDOM ( $\mathrm{a}_{\mathrm{g}}$ ) absorption at $443 \mathrm{~nm}$ (right panels) from MODIS Aqua. 


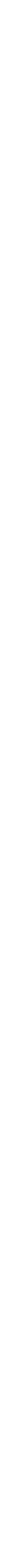


Locations of primary and near-shore outfall pipes are shown in red and grey, respectively.

Figure 6. Glider mean plume profiles and mean non-plume profiles of temperature (A), chlorophyll- $a$ fluorescence (B), CDOM fluorescence (C), and salinity (D) \pm a standard deviation from throughout the diversion. Also, shown is the profile of the estimated depth dependent effect size (Cohen's d) of each variable (E).

Figure 7. An example of glider curtain plots obtained during the diversion (29 September to 3 October) showing temperature (A), chlorophyll- $a$ fluorescence (B), Sigma $\theta$ (C), CDOM fluorescence (D) and salinity (E). Map of glider paths (F) occupied during the diversion corresponding to curtain plots are depicted in dark grey, and all transects in light grey.

Figure 8. An example of post-diversion glider curtain plots from 5-8 October (3-6 days post-diversion) showing temperature (A), chlorophyll- $a$ fluorescence (B), Sigma $\theta$ (C), CDOM fluorescence (D) and salinity (E). The map (F) of the transect line presented here for the curtain plots is depicted in dark grey, and all transects conducted during the postdiversion period are shown in light grey. 

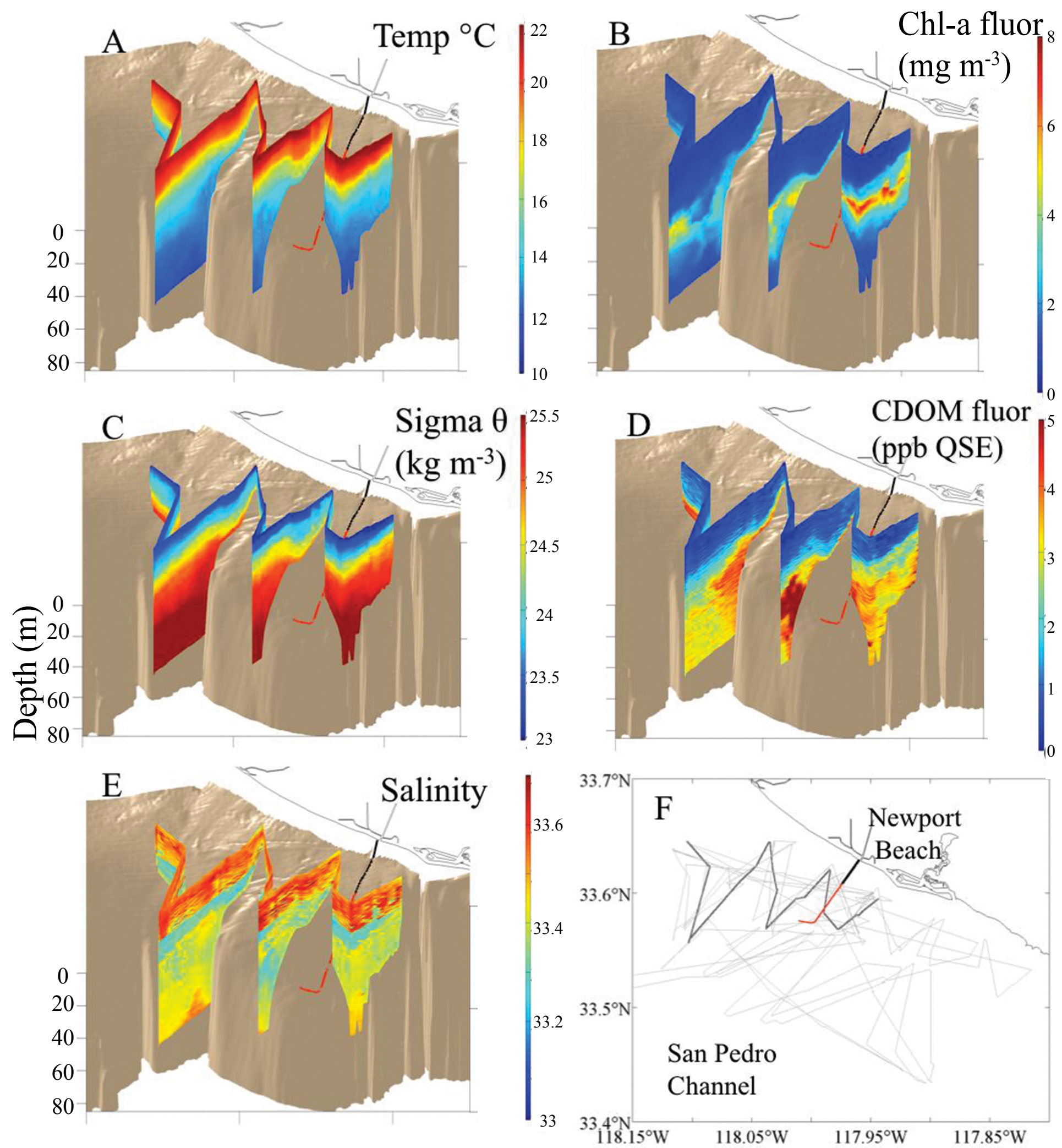
Pre-Diversion 7-9 Sept

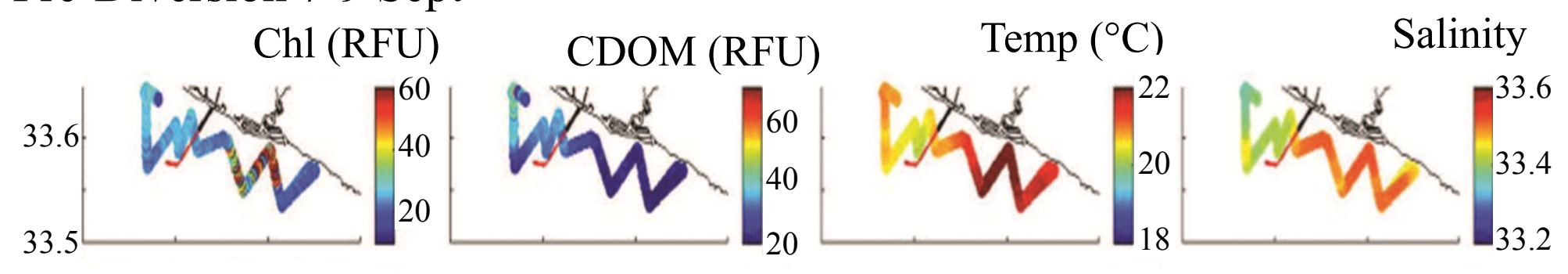

Diversion 11-13 Sept
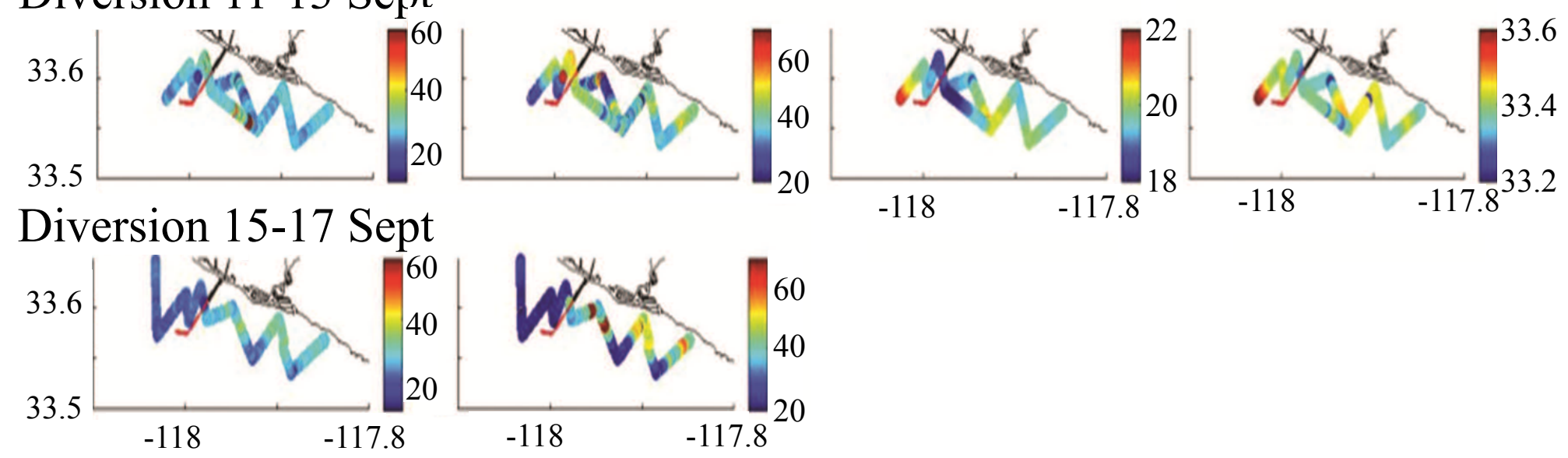


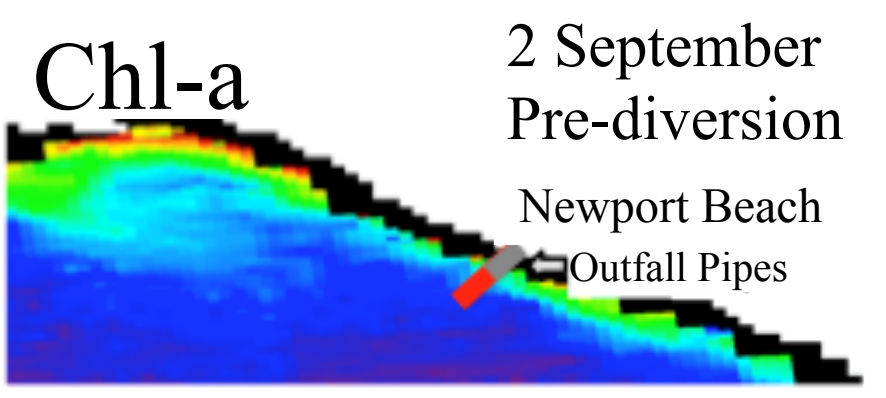

\section{CDOM absorption}

20 September
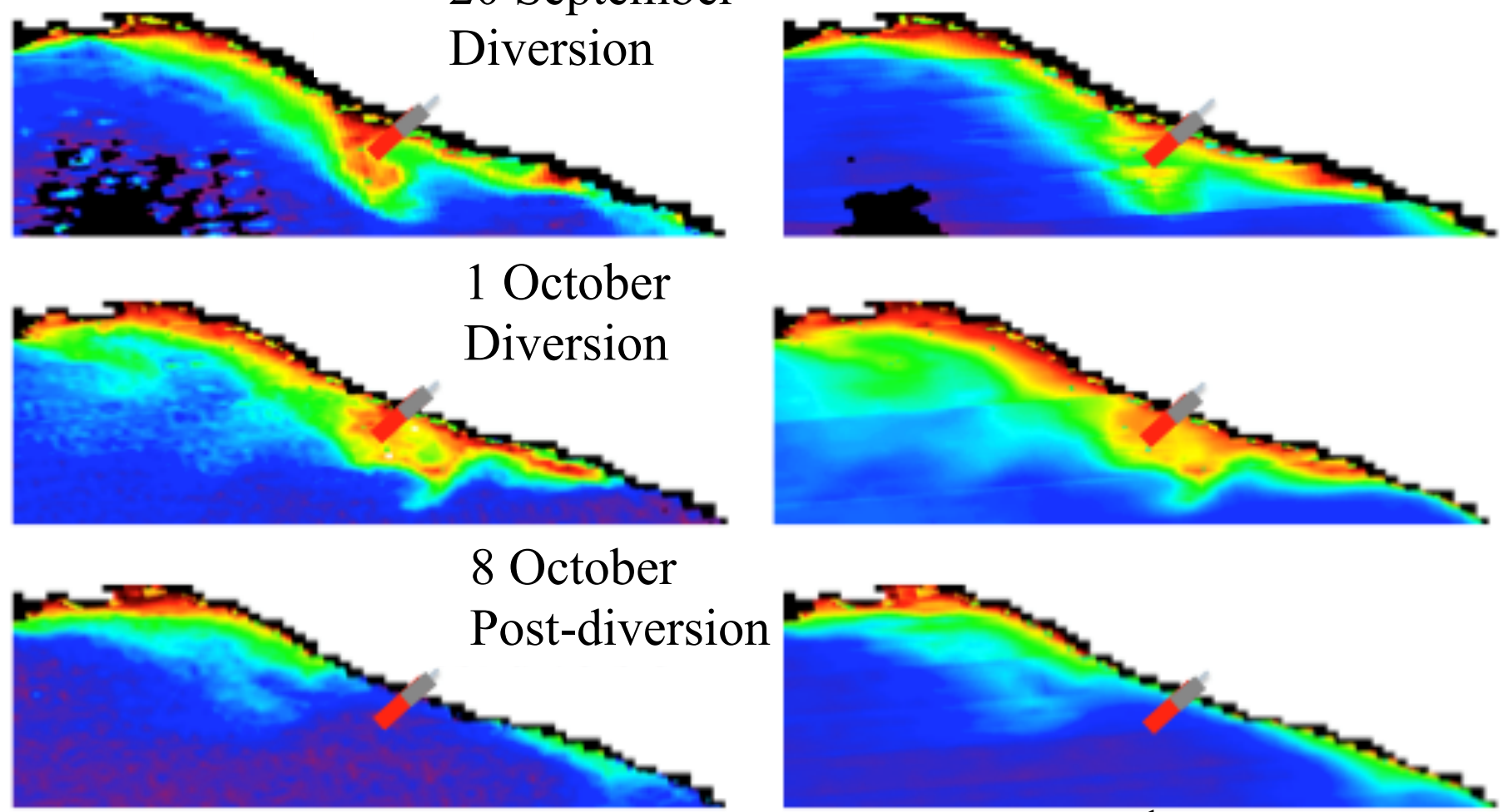

Chl (mg m $\left.{ }^{-3}\right)$

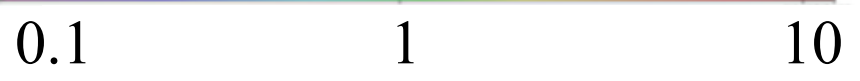

10

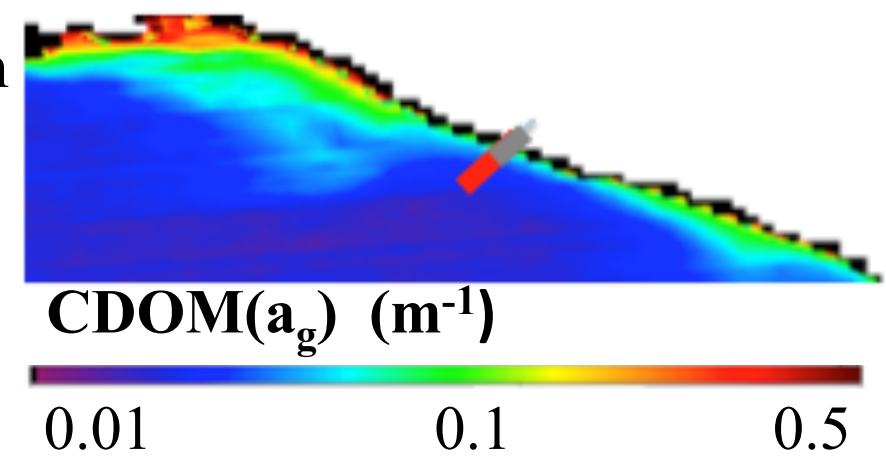


Figure6_greyscale
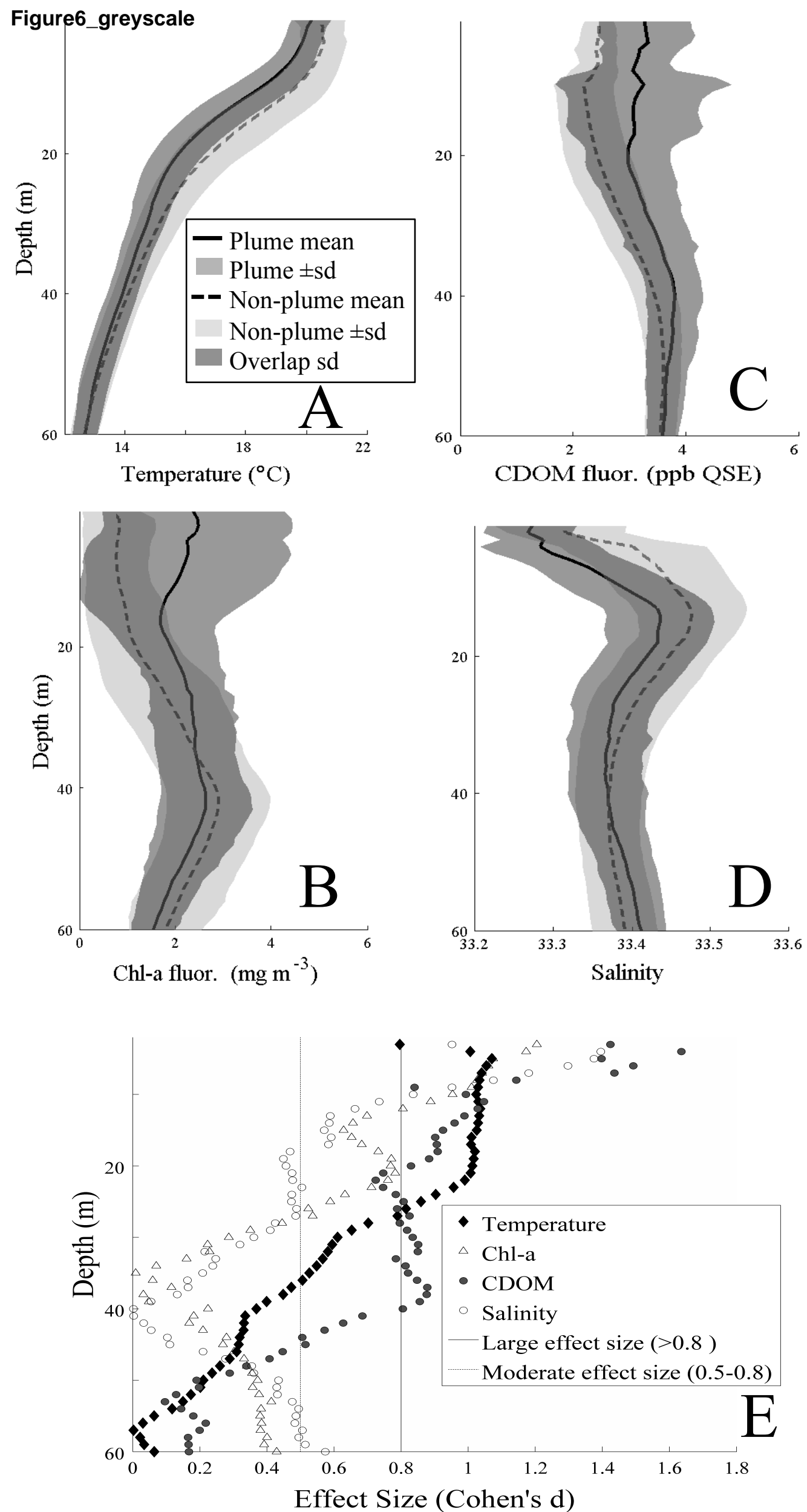


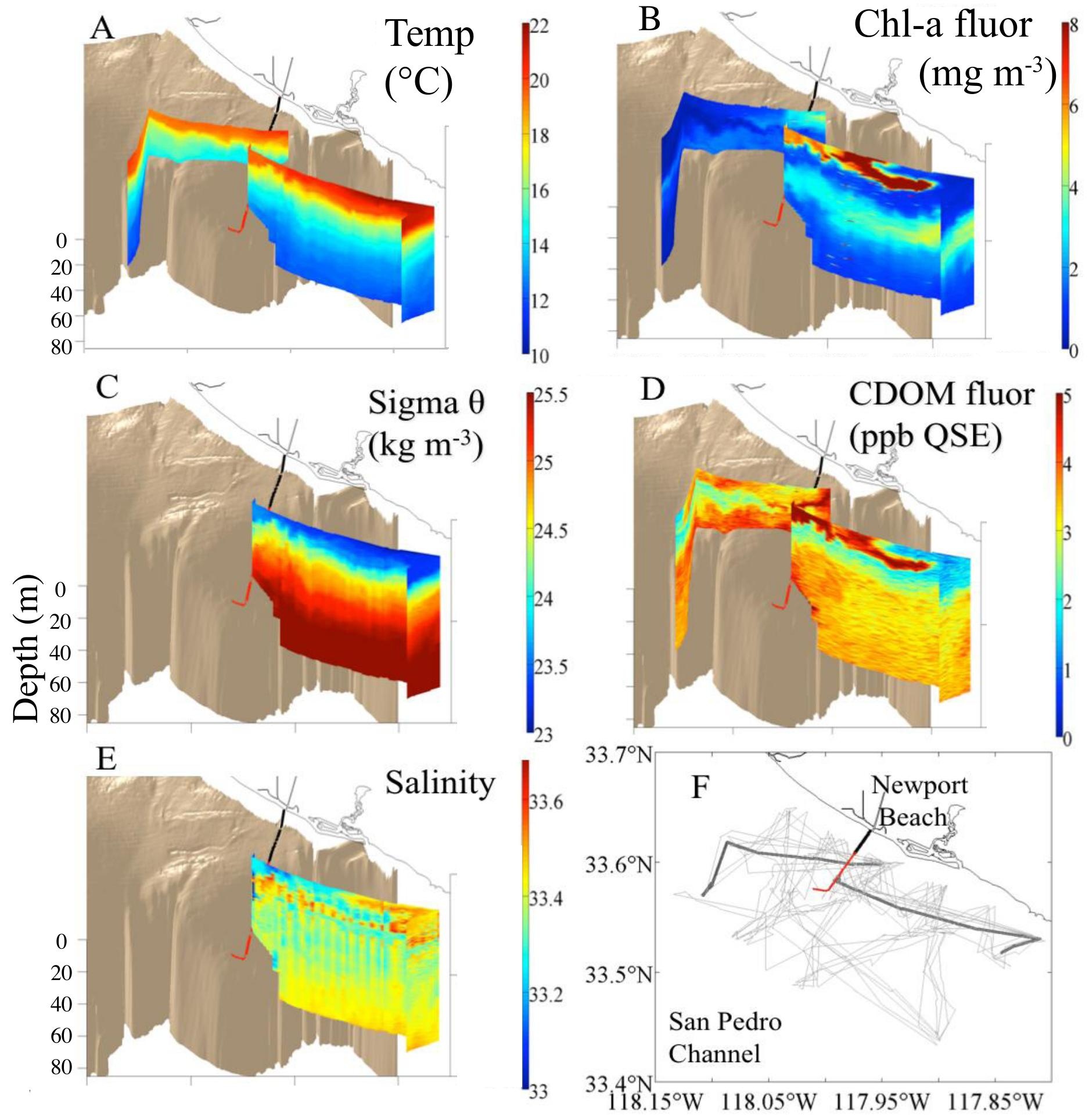


